\title{
He Almost Forgets That There is a Maker of the World
}

BEN SPATZ (D)

N. EDA ERÇIN (1)

CAROLINE GATT (D)

AGNIESZKA MENDEL

*Author affiliations can be found in the back matter of this article
SPECIAL COLLECTION: SPECIAL ISSUE OF ILLUMINATED VIDEOS VIDEO ARTICLE

\section{(1) 1} Open Library of Humanities

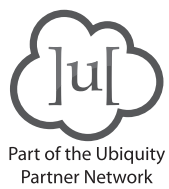

CORRESPONDING AUTHOR:

\section{Ben Spatz}

University of Huddersfield, GB b.spatz@hud.ac.uk

KEYWORDS:

Judaica; cultural theory; theatre laboratory; embodied research; illuminated video

TO CITE THIS ARTICLE: Spatz, B, Erçin, NE, Gatt, C and Mendel, A. 2021. He Almost Forgets That There is a Maker of the World. Journal of Embodied Research, 4(2): 7 (32:06). DOI: https://doi. org/10.16995/jer.71 
VIDEO ARTICLE

Available to view here: https://doi.org/10.16995/jer.71.

Available for download here: https://doi.org/10.16995/jer.71.s1.

STILLS FROM THE VIDEO ARTICLE
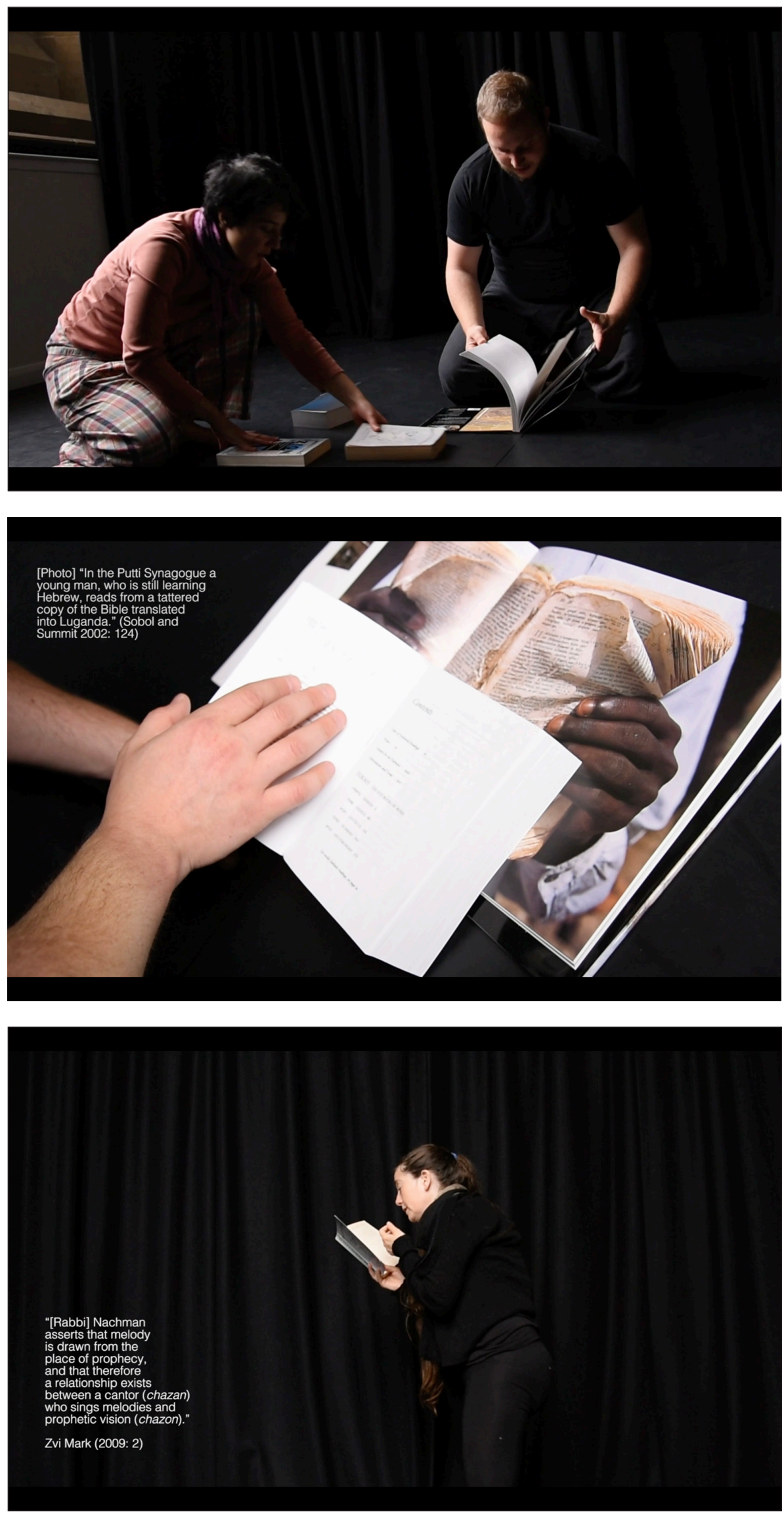


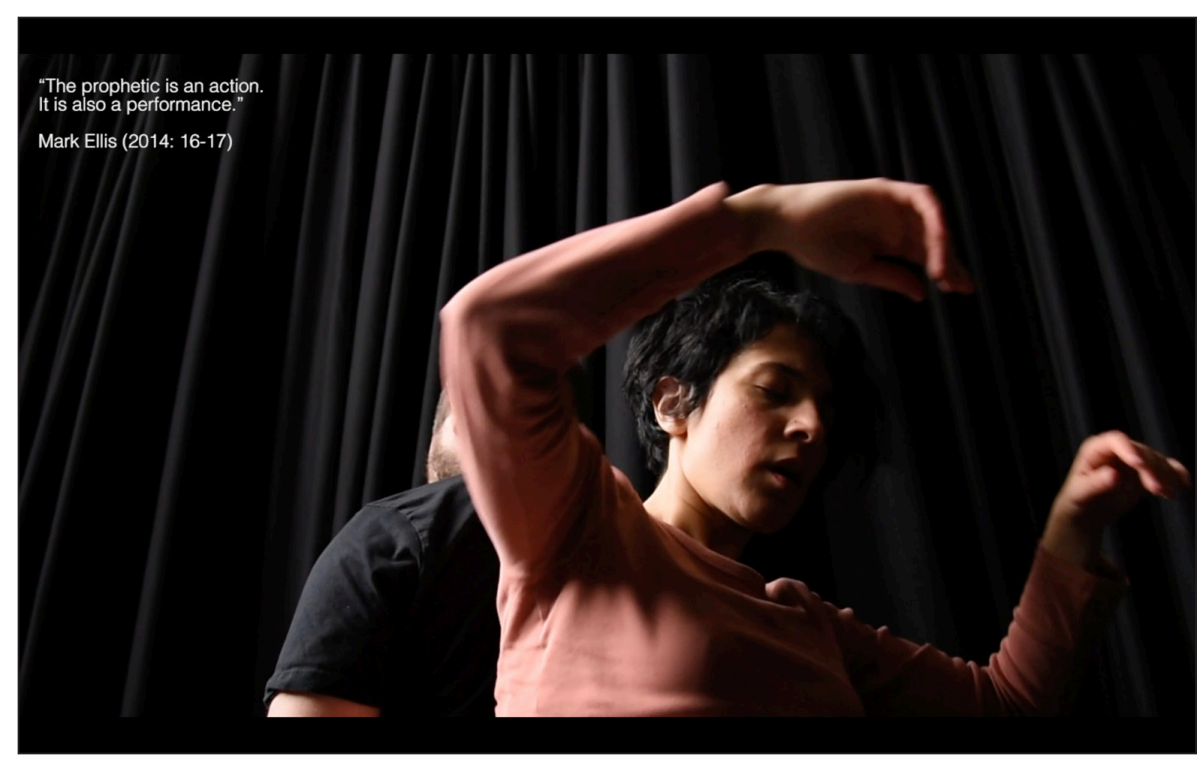

\section{VIDEO ARTICLE TRANSCRIPT}

[Note: This is a transcript of a video article. Individual elements from the transcript, such as metadata and reference lists, may appear more than once in the document, in order to be properly read and accessed by automated systems. The transcript can be used as a placeholder or reference when it is not possible to embed the actual video, which can be found by following the DOI.]

[00:10]

Judaica:

Embodied

Laboratory

for Songwork

Week Nine

Session \#49

29 June 2017

Huddersfield, UK

\section{He Almost Forgets That There is a Maker of the World}

\section{a video essay with Judaica}

[Book] Abayudaya: The Jews of Uganda. Richard Sobol (text and photographs) and Jeffrey A. Summit (recordings). New York: Abbeville Press (2002).

Mukama n'amugamba Musa nti Ekibonoobono kimu nate kye ndimuleetera Falaawo ne Misiri; oluvannyuma alibaleka okuvaamu: bw'alibaleka, mazima alobagobera ddala muno.

Mukama n'amugamba Musa nti Ekibonoobono kimu nate kye ndimuleetera Falaawo ne Misiri; oluvannyuma alibaleka okuvaamu: bw'alibaleka, mazima alobagobera ddala muno.

And the LORD said to Moses, "I will bring but one more plague upon Pharoah and upon Egypt; after that he shall let you go from here; indeed, when he lets you go, he will drive you out of here one and all" (Exodus 11:1)

[Book] Tanakh: The Holy Scriptures. The New JPS Translation according to the Traditional Hebrew Text. Philadelphia: The Jewish Publication Society (1985).

[Photo] "In the Putti Synagogue a young man, who is still learning Hebrew, reads from a tattered copy of the Bible translated into Luganda." (Sobol and Summit 2002: 124)

"How then does one approach an identity as a research problem? In the case of jewishness, the debate over what and who is jewish has existed for centuries or millennia, yet its contemporary configuration is unique. [...T] he scholarly discipline of Jewish studies has been 
slow to situate jewishness within a broader framework of critical identity theory and politics." Ben Spatz (2019: 70)

Gilead. Jephthah the Gileadite was an able warrior, who was the son of a prostitute.

Jephthah's father was Gilead.

"[A]n attempt to decolonize jewish identity through experimental practice need not be metaphorical even if it is molecular. The premise of embodied research is that technique and identity can be substantively - not metaphorically - altered through embodied research, even if this initially takes place on a micro-political scale." Spatz (2019: 71)

And he almost forgets that there is a maker of the world.

"Which ingredients need to come together, and how should their encounter be structured, in order to produce what could later be analysed as fragments or molecules of decolonial judaism? What form might these particles take and how could their presence or validity be assessed?" Spatz (2019: 71)

"Over eighty percent of global Jewry is concentrated in North America, Europe, and Israel/ Palestine, and they are typically (and uniformly) portrayed as integral members of Western civilization... Ironically this represents a permutation of the same narrative that racialized their grandparents and even parents until as recently as a few decades ago." Santiago Slabodsky (2014: 5)

"The first challenge is the interrelation between existential conditions and epistemological creativity. If it is true that Jews have undergone a racial re-classification, can they ... still be a compelling source of decolonial proposals?" Slabodsky (2014: 30)

"[T]here is a clear distinction between the hybrid and the border thinker. The former attempts to undermine colonial dualisms by dissolving identities; the latter creatively develops identities." Slabodsky (2014: 35)

"[W]e need to return to the chasm that makes translation possible and consider what it might mean for one ethical resource from the past to enter into a field of translation with resources from quite distinct and internally complicated traditions." Judith Butler (2012: 11)

"This is the paradoxical power of diaspora. On the one hand, everything that defines us is compounded of all the questions of our ancestors. On the other hand, everything is permanently at risk." Jonathan Boyarin and Daniel Boyarin (2002: 4)

"If we wish to find [...] not only the continued relevance of the critical humanities to our times but the keys to rendering an engaged humanities a force contending with [...] the planetary forcings of climate change we now confront, then [...] we will need to find a method for doing so, a method adequate to the situation of our multiscaled, period-multiplying Anthropocene times." Ian Baucom (2020: 8)

"I wish to theorize the ways that the digital regime makes perceptible a set of transformations in how notions of identity and belonging are mediated. [...] The transformations I explore here point to a renewed interest in forging dynamic modes of commonality and belonging that exceed the prior logics of identity politics while remaining invested in the workings of difference." Kara Keeling (2011: 56)

"[W]e argue that digital video is not just a new way of presenting but a new way of practicing field research. ... A videoactive context ... is a social situation with potential and known recording capacity, created by the presence of a loaded camera." Wesley Shrum et al. (2005)

“What could standing on one's own ('Jewish') legs mean for the Jewish Studies aspirant (including the limit-case of one who may well not be Jewish)? [...] What might it mean to really go through the university 'to get out of it again'? Short of nonmatriculation or simply quitting, does that indicate a constructive possibility?" Adam Zachary Newton (2019: 156)

[Book] Tales of the Hasidim. Martin Buber. Translated by Olga Marx. Foreword by Chaim Potok. New York: Schocken Books (1991). 
"The visibility of the multitude of relations that compose a book are the key to the voices of the pages, to the liveliness of books... A book, text, will become something different depending on how one is taught to read it." Caroline Gatt $(2017$ : 73-74, 78)

"Whenever you read a book and meet with any wholesome maxims by which you feel your soul stirred or enthralled, do not trust merely to the powers of your native abilities, but make a point of learning them by heart...” Augustine/Petrarch in Carruthers (2008: 203)

... of Orthodox forces ... secularism ... political Zionism ... heady with the prospect of participating as partners in Western civilization, attempting to enter fully the mainstream of European life-some by denying their inherited culture, others by taking with them a personal vision of it into the wider world. Those who broke entirely with Judaism and for one reason or another chose later to return, often did so on their own terms. Gone forever was the time when an apostate, like the seventeenthcentury Amsterdam Jew, Uriel da Costa, would return unconditionally ... at the cost of public contrition and humiliation to ... faith established and maintained by repressive communal elders.

The First Zionist Congress, held in Basle in 1897, brought Buber back into the Jewish community. Until then he had lived, as he put it, "in the 'world of confusion,' the mythical dwelling place of the wandering souls ... in versatile fullness of spirit, but without Judaism, without humanity, and without the presence of the divine." He returned as a Western Jew, who had broken with Jewish observance during adolescence but had retained a deep awareness of the extent to which Western notions of the individual - ah! — and the community were rooted in the Bible and the Hebraic tradition.

The First Zionist Congress, held in Basle in 1897, brought Buber back into the Jewish community. Until then he had lived, as he put it, "in the 'world of confusion,' the mythical dwelling place of the wandering souls ... in versatile fullness of spirit, but without Judaism, without humanity, and without the presence of the divine." He returned as a Western Jew, who had broken with Jewish observance during adolescence but had retained a deep awareness of the extent to which Western notions of the individual and the community were rooted in the Bible and the Hebraic tradition.

Chaim Potok in Buber (1991: viii)

Die Welt!

[Song] 'Nigun Simcha' (Joyful Tune). Traditional. From a recording by Avraham Fried. The Baal Shem Tov's Song. New York: Sameach Music (2010).

... the mythical dwelling place of the wandering souls ... wandering souls ...

"The word is intrinsically sonorous, and the role of the voice is not so much to produce sounds of words but, in song, to let them go forth..." Tim Ingold (2007: 7)

... versatile fullness of spirit, but without Judaism, without humanity, and without the presence of the divine ... mythical dwelling place of the wandering souls ... versatile fullness of spirit ... but without the presence of the divine ...

"[Rabbi] Nachman asserts that melody is drawn from the place of prophecy, and that therefore a relationship exists between a cantor (chazan) who sings melodies and prophetic vision (chazon)." Zvi Mark (2009: 2)

“The prophetic is an action. It is also a performance." Mark Ellis (2014: 16-17)

“Today, even the Jewish prophetic is tainted with colonial sensibilities." Ellis (2014: 367)

I opened a little book ... that is the testament of Rabbi Israel Baal-Shem - and the words flashed towards me, "He takes unto himself the quality of fervor. He rises from sleep with fervor, for he is hallowed and become another man and is worthy to create..."

Martin Buber (1991: viii) 
I opened a little book ... that is the testament of Rabbi Israel Baal-Shem - and the words flashed towards me, "He takes unto himself the quality of fervor. He rises from sleep with fervor, for he is hallowed and become another man and is worthy to create and is become like the Holy One, blessed be He ... It was then that, overpowered in an instant, I experienced the Hasidic soul ...

[Book] Wrestling with Zion: Progressive Jewish-American Responses to the Israeli-Palestinian Conflict. Edited by Tony Kushner and Alisa Solomon. New York: Grove Press, 2003.

This is my resignation... From...

This is my resignation — haha!

This is my resignation from!

From the editorial board...

From the Editorial Advisory Board of Sh'ma.

The contributions from me that you have published over the years have been few in number and less than earth-shaking in import, and you are therefore not deprived of a great editorial asset. In any case, my resignation has almost nothing to do with my relationship to Sh'ma as such. It is the consequence of a very much superordinated [reorientation] by me of my relationship to the Jewish community in the largest sense. Let me explain as best I can.

For a generation now, I have been deeply troubled by the chauvinistic assumptions and repressive effects of Israeli nationalism. I have experienced the War on Lebanon of the past few weeks as a turning point in Jewish history and consciousness exceeded in importance only by the End of the Second Commonwealth and the Holocaust. I have resisted the interference for over thirty years, but the War on Lebanon has now made clear to me that the resumption of political power by the Jewish people after two thousand years of diaspora has been a tragedy of historical dimensions. The State of Israel has demanded recognition a the modern political incarnation of the Jewish people. To grant that is to betray the Jewish tradition.

For a generation now, I have been deeply troubled by the chauvinistic assumptions and repressive effects of Israeli nationalism. I have experienced the War on Lebanon of the past few weeks as a turning point in Jewish history and consciousness exceed in importance perhaps only by the End of the Second Commonwealth and the Holocaust. I have resisted the inference for over thirty years, but the War on Lebanon has now made clear to me that the resumption of political power by the Jewish people after two thousand years of diaspora has been a tragedy of historical dimensions. The State of Israel has demanded recognition as the modern political incarnation of the Jewish people. To grant that is to betray the Jewish tradition.

Henry Schwarzschild in Kushner and Solomon (2003: 35-36)

The State of Israel and its supporters have probably been right all along in arguing that political power comes at the price of the normal detritus of the nation state, such as Jewish criminals, prostitutes, and generals. They may [also] be right in asserting that the War on Lebanon is the sort of thing a Jewish state has to do to survive. I am not disposed to await the outcome of debates by politicians and theologians on whether the threat from the Palestine Liberation Organization was sufficiently clear and present to justify the killing of so many Lebanese and Palestinian men, women, and children, or only so many. I will not avoid an unambiguous response to the Israeli [army turning] West Beirut into another Warsaw ghetto.

I now conclude and avow that the price of a Jewish state is, to me, Jewishly unacceptable and that the existence of this (or any similar) Jewish [ethno-religious] nation state is a Jewish, i.e. a human and moral, disaster and violates every remaining value for which Judaism and Jews might exist in history. The lethal military triumphalism and corrosive racism that inheres in the State and in its supporters (both there and here) are profoundly abhorrent to me. So is the message that [goes now] forth to the nations of the world that the Jewish people claim the right to impose a holocaust on others in order to preserve its State. 
For several decades, I have supported those minority forces in and for the State that wanted to salvage the values of peace and [justice,] social justice that the Jewish tradition commands. The "blitzkrieg" in Lebanon, terrifying and Teutonic in its ruthlessness, shows how vain those hopes have been.

I now renounce the state of Israel

I now renounce the State of Israel, disavow any political connection or emotional obligation to it, and declare myself its enemy. I retain, of course, the same deep concern for its inhabitants, Jewish, Arab, and other, that I hold for all humankind.

I remain a member of the Jewish people.

I remain a member of the Jewish people-indeed, I have no other inner identity. But the State of Israel has now also triumphed over the Jewish people and its history, for the time being at least. I deem it possible that the State, morally bankrupted and mortally endangered by its victories, will prove essential to the survival of the Jewish people and that it may likely take the Jewish people with it to eventual extinction. Yet I believe that the death of the Jewish people would not be inherently more tragic than the death of the Palestinian people that Israel and its supporters evidently seek or at least accept as the cost of the "security" of the State of Israel. The price of the millennial survival of the Jewish people has been high; I did not think the point was to make others pay [for] it. That moral scandal intolerably assaults the accumulated values of Jewish history and tradition.

If those be the places where the State of Israel chooses to stand, I cannot stand with it. I therefore resign all connections with Jewish political and public institutions that will not radically oppose the State and its claim to Jewish legitimacy. Sh'ma is one of those.

"[I]t is not enough simply to classify Israel — or, for that matter, anywhere else - as settlercolonial. In each case, the site-specific workings of the varied local expressions of the settler drive to eliminate Native territoriality have to be reconstructed on their own terms... Only on this basis can we begin to derive general principles on which to base cross-colonial, crosscommunity, anti-racist solidarities.” Patrick Wolfe (2016: 270)

Have you resigned?

Have I resigned?

He rises up with fervor from his bed!

In that instant overpowered...

[Song] "Tulo, tulo" (Sleep, sleep). Traditional. From a recording by Phyllis Nafuna. Abayudaya: Music from the Jewish People of Uganda. Washington, DC: Smithsonian Folkways Recordings (2003).

Tulo tulo kwata amwana, bwoto mukwate nga olimulogo, ssebo wulila

Tulo tulo kwata amwana, bwoto mukwate nga olimulogo, ssebo wulila

Njagala ngendeko kumazina nzine kundongo, nkyuse kubulamu obulamu bwakuleka $[\times 3]$

[Photo] "Rabbi Mishael Biroji reciting morning prayers at the Moses Synagogue." (Sobol and Summit 2002)

"Today, we Abayudaya number between 2,000 and 3,000. There are about eight synagogues scattered across eastern Uganda, one in the north, and a meeting house in the capital, Kampala." Mugoya Shadrah Levi (2017)

"In this popular Baganda lullaby, a babysitter sings, 'Sleep sleep, take the child... I want to go dancing, change my life. You only live once."” (From the album notes.)

"Only by entering into a field of cultural translation do particular ethical resources become generalizable and effective." Judith Butler (2012: 12) 
Laba, laba

Laba bwekuliokulungi bwekusanyusa

abaluganda okutula

[x10]

[Song] "Hinei ma tov" (Behold how good). Abayudaya: Music from the Jewish People of Uganda. Washington, DC: Smithsonian Folkways Recordings (2003).

"The text of this song is from Psalm 133. The melody is a group composition. This song is sung on happy occasions. Text in Luganda and Hebrew." (From the album notes)

Hinei, hinei

Hinei ma tovu umanayim oo

Sheveti ahim gam yahadu

[x17]

"The Abayudaya's Hebrew pronunciation is influenced by Luganda, where many words end with a vowel. As a result, when singing in Hebrew, the Abayudaya often add a vowel to the end of a word." (From the album notes)

"After living through isolation and persecution, we find it hard to believe that Jews halfway around the world are singing our music. Now we feel that we have arrived and are one people. Our music is important, and our compositions are respected." (J. J. Keki in Sobol and Summit 2002: 29)

"The question for embodied and artistic research is then twofold: First, how to produce uncommon deconstructions, fragmentations, collisions and reconstructions of identity in practice? How to reveal and unfold, unbundle and open up the molecular flows of identity, in order to recombine them in new ways? And second, how to create a trace or document of these collisions and recombinations, so that they can be analysed and shared?" (Spatz 2019: 77)

"My body, as I encounter it through the editor function, is made up of elements and traces of my being as they were summoned and selected in that moment by my companions. Our practicing, directing, and videographic bodies mingle in the resulting video material in a way that is both documentary and aesthetic, both critical and erotic. At the same time, history proper is present in the gendered, racial, educational, and other backgrounds and inheritances that make up our more sedimented layers of embodiment and place." Spatz (2020: 171)

"[B]ecause the physical body and its techniques are never abstract, but rather ineluctably located within a historical moment and a cultural/political system, any confrontation between two or more physical techniques has unavoidable historical and political resonances." Profeta (2015: 204)

"What are the conditions according to which one could undertake a Jewish decolonial reading of the geopolitical scene?" Slabodsky (2014: 210)

“[Y]ou are both familiar and strange to me..." Houria Bouteldja (2017: 67)

[30:03]

"Like the pictures in a film, epic theater moves in spurts. [...]

The songs, the captions, the lifeless conventions

set off one situation from another.

This brings about intervals which, if anything,

impair the illusion of the audience and

paralyze its readiness for empathy."

Walter Benjamin

(1969: 153)

"He Almost Forgets That There is a Maker of the World."

Illuminated video by Ben Spatz with Nazlıhan Eda Erçin, 
Caroline Gatt, and Agnieszka Mendel.

What can jewishness be - a nation, a race, a religion, a style of humor? A history of diaspora? A relation to whiteness? A commandment to work for justice? Where is jewishness in the body?

In this illuminated video essay, 30 minutes of uncut experimental songwork practice are augmented by 50 annotations or "illuminations."

These are embedded into the video, as they would more commonly be embedded in prose, providing a dense critical context for what unfolds.

A handful of songs provide the spine of the work, while four carefully selected books stud the flow of song and evoke the elusive potential of a jewishness to come: antique, mystical, anticolonial, renewed.

The four practitioner-researchers draw on their shared backgrounds in laboratory theatre to explore these materials in a dynamic flow of action and interaction.

The uncut video grounds the viewer in the temporality of the practice and demands a close reading of the documented moment.

The annotations enhance, clarify, and in some cases critique or interrogate the embodied research, offering a layer of commentary as a contemporary riff on talmudic ways of thinking.

"He Almost Forgets..." was created through a new audiovisual embodied laboratory research method (Spatz 2020).

It demonstrates the capacity of artistic research to generate new molecular identities and alternative forms of knowledge.

\section{CONTRIBUTORS}

Performance:

N. Eda Erçin, Caroline Gatt, Ben Spatz

Videography:

Agnieszka Mendel

Annotations:

Ben Spatz

Introduction of books into the lab:

Caroline Gatt

N. Eda Erçin (Turkey) is a performer/researcher with a background in sociology and ethnography. She holds a practice-based PhD in Drama from the University of Exeter, specializing in the performance of gender, ethnicity and language. She is currently teaching in Communication Studies at Louisiana State University and managing the HopKins Black Box Performance Laboratory. Her work has been published in Performance Research and Theatre, Dance and Performance Training.

Caroline Gatt (Malta) is Senior Research Fellow, Institute of Cultural Anthropology and European Ethnology, University of Graz and Co-Investigator on the project "(Musical) Improvisation and Ethics" funded by the Austrian Science Fund. She is an anthropologist and performer, author of "Breathing Beyond Embodiment: Exploring Emergence, Grief and Song in Laboratory Theatre" (2020) and An Ethnography of Global Environmentalism: Becoming Friends of the Earth (2018) and editor of TITG Chapbooks (2022 with Joss Allen) and The Voices of the Pages (2017/2018).

Agnieskza Mendel (Poland) is a vocalist, actress, and coach of voice and stage presence. She graduated from the Adam Mickiewicz University in Pozna, Poland in Ethnology and Cultural Anthropology and the Gardzienice Theater Practices Academy. For 15 years, she was closely associated with the European Center for Theater Practices Gardzienice, where she created leading acting and vocal roles in performances by Włodzimierz Staniewski. As part of her own artistic activity, she composes, writes texts and performs concerts. She is the leader of several music groups, including Tara Gayan and Yaron Trio. She has received numerous awards and scholarships in the field of culture.

Ben Spatz (United States) is a nonbinary researcher and theorist of embodied practice. They are Senior Lecturer in Drama, Theatre and Performance at the University of Huddersfield 
and author of three books: What a Body Can Do (Routledge 2015), Blue Sky Body (Routledge 2020), and Making a Laboratory (Punctum 2020). Ben is also founder and editor of the videographic Journal of Embodied Research and the Advanced Methods imprint from Punctum Books. They have more than two decades of experience as a performer and director of contemporary theatre and have been invited to present their work at more than thirty institutions in seventeen countries.

\section{TEXTS CITED}

Arsenjuk, Luka (2016) "to speak, to hold, to live by the image." in The Essay Film: Dialogue, Politics, Utopia. Eds. Elizabeth A. Papazian and Caroline Eades. London: Wallflower Press.

Baucom, Ian (2020) History $4^{\circ}$ Celsius:Search for a Method in the Age of the Anthropocene. Durham and London: Duke University Press.

Benjamin, Walter (1969) Illuminations. New York: Schocken Books.

Bouteldja, Houria (2017) Whites, Jews, and Us: Toward a Politics of Revolutionary Love. Translated by Rachel Valinsky. New York: Semiotext(e).

Boyarin, Jonathan and Daniel Boyarin (2002) The Powers of Diaspora: Two Essays on the Relevance of Jewish Culture. Minneapolis: University of Minnesota Press.

Buber, Martin (1991) Tales of the Hasidim. Translated by Olga Marx. New York: Schocken Books.

Butler, Judith (2013) Parting Ways: Jewishness and the Critique of Zionism. New York: Columbia University Press.

Carruthers, Mary (2008 [1990]) The Book of Memory: A Study of Memory in Medieval Culture. Cambridge: Cambridge University Press.

Ellis, Mark H. (2014) Future of the Prophetic: Israel's Ancient Wisdom Re-presented. Minneapolis: Fortress Press.

Gatt, Caroline, ed. The Voices of the Pages. Knowing from the Inside. University of Aberdeen (2017).

Ingold, Tim (2007) Lines: A Brief History. New York and London: Routledge.

Keeling, Kara (2011) "I = Another: Digital Identity Politics." In Strange Affinities:

The Gender and Sexual Politics of Comparative Racialization. Eds. Grace Kyungwon Hong and Roderick A. Ferguson. Durham and London: Duke University Press (53-75).

Kushner, Tony and Alisa Solomon, eds. Wrestling with Zion: Progressive Jewish-American Responses to the Israeli-Palestinian Conflict. New York: Grove Press (2003).

Mark, Zvi (2009) Mysticism and Madness: The Religious Thought of Rabbi Nachman of Bratslav. New York: Continuum.

Newton, Adam Zachary (2019) Jewish Studies as Counterlife: A Report to the Academy. New York: Fordham University Press.

Profeta, Katherine (2015) Dramaturgy in Motion: At Work on Dance and Movement Performance. Madison: University of Wisconsin Press.

Shrum, Wesley, Ricardo Duque, and Timothy Brown (2005) "Digital Video as Research Practice: Methodology for the Millennium." Journal of Research Practice 1.1.

Slabodsky, Santiago (2014) Decolonial Judaism: Triumphal Failures of Barbaric Thinking. Basingstoke: Palgrave Macmillan.

Sobol, Richard (text and photographs) and Jeffrey A. Summit (recordings). Abayudaya: The Jews of Uganda. New York: Abbeville Press (2002).

Spatz, Ben (2019) "Molecular Identities: Digital Archives and Decolonial Judaism in a Laboratory of Song." Performance Research 24.1 (66-79).

Spatz, Ben (2020) Making a Laboratory: Dynamic Configurations with Transversal Video. New York: Punctum Books. 
Tanakh: The Holy Scriptures. The New JPS Translation according to the Traditional Hebrew Text. Philadelphia: The Jewish Publication Society (1985).

Wolfe, Patrick (2015) Traces of History: Elementary Structures of Race. New York: Verso Books.

\section{RECORDINGS CITED}

Abayudaya: Music from the Jewish People of Uganda. Recorded and with album notes by Jeffrey A. Summit. Washington, DC: Smithsonian Folkways Recordings (2003).

Fried, Avraham. The Baal Shem Tov's Song. New York: Sameach Music (2010).

\section{ACKNOWLEDGMENTS}

This video was recorded with a Nikon D750 camera

in Rehearsal Room 1

Centre for Psychophysical Performance Research

Sir Patrick Stewart Building

University of Huddersfield

The title is from Buber (1991: 69).

Special thanks to Stuart Katwikirize for help with Luganda translation.

See also: <https://www.wordproject.org/bibles/lug/02/11.htm\#0>

Support was provided by:

Judaica: An Embodied Laboratory for Song-Action

UK Arts and Humanities Research Council (2016-2018)

University of Huddersfield

and

Knowing from the Inside

European Research Council (2013-2018)

University of Aberdeen

More information:

Urban Research Theater

www.urbanresearchtheater.com

\section{COMPETING INTERESTS}

The authors have no competing interests to declare.

\section{AUTHOR AFFILIATIONS}

Ben Spatz (D) orcid.org/0000-0002-1466-6634

University of Huddersfield, GB

N. Eda Erçin (D) orcid.org/0000-0002-2707-9543

Louisiana State University, US

Caroline Gatt (D) orcid.org/0000-0003-0509-4010

University of Graz, AT

\section{Agnieszka Mendel}

Independent Artist, PL

\section{REFERENCES}

Baucom, I. 2020. History $4^{\circ}$ Celsius:Search for a Method in the Age of the Anthropocene. Durham and London: Duke University Press. DOI: https://doi.org/10.1515/9781478012030

Benjamin, W. 1969. Illuminations. New York: Schocken Books.

Bouteldja, H. 2017. Whites, Jews, and Us: Toward a Politics of Revolutionary Love. Translated by Rachel Valinsky. New York: Semiotext(e).

Boyarin, J and Boyarin, D. 2002. The Powers of Diaspora: Two Essays on the Relevance of Jewish Culture. Minneapolis: University of Minnesota Press.

Buber, M. 1991. Tales of the Hasidim. Translated by Olga Marx. New York: Schocken Books. 
Butler, J. 2012. Parting Ways: Jewishness and the Critique of Zionism. New York: Columbia University Press. Carruthers, M. 2008 [1990]. The Book of Memory: A Study of Memory in Medieval Culture. Cambridge: Cambridge University Press. DOI: https://doi.org/10.1017/CB09781107051126

Ellis, MH. 2014. Future of the Prophetic: Israel's Ancient Wisdom Re-presented. Minneapolis: Fortress Press. DOI: https://doi.org/10.2307/j.ctt22nm79b

Gatt, C. (ed.) 2017. The Voices of the Pages. Knowing from the Inside. University of Aberdeen.

Ingold, T. 2007. Lines: A Brief History. New York and London: Routledge. DOI: https://doi. org/10.4324/9780203961155

Keeling, K. 2011. I = Another: Digital Identity Politics. In Strange Affinities: The Gender and Sexual Politics of Comparative Racialization. Hong, GK and Ferguson, RA (eds.), 53-75. Durham and London: Duke University Press. DOI: https://doi.org/10.1215/9780822394075-003

Kushner, T and Solomon, A. (eds.) 2003. Wrestling with Zion: Progressive Jewish-American Responses to the Israeli-Palestinian Conflict. New York: Grove Press.

Mark, Z. 2009. Mysticism and Madness: The Religious Thought of Rabbi Nachman of Bratslav. New York: Continuum.

Newton, AZ. 2019. Jewish Studies as Counterlife: A Report to the Academy. New York: Fordham University Press. DOI: $h$ ttps://doi.org/10.5422/fordham/9780823283958.001.0001

Profeta, K. 2015. Dramaturgy in Motion: At Work on Dance and Movement Performance. Madison: University of Wisconsin Press.

Shrum, W, Duque, $\mathbf{R}$ and Brown, T. 2005. Digital Video as Research Practice: Methodology for the Millennium. Journal of Research Practice, 1(1).

Slabodsky, S. 2014. Decolonial Judaism: Triumphal Failures of Barbaric Thinking. Basingstoke: Palgrave Macmillan. DOI: https://doi.org/10.1057/9781137345837

Sobol, R. 2002. (text and photographs) and Jeffrey A. Summit (recordings). Abayudaya: The Jews of Uganda. New York: Abbeville Press.

Spatz, B. 2019. Molecular Identities: Digital Archives and Decolonial Judaism in a Laboratory of Song. Performance Research, 24(1): 66-79. DOI: https://doi.org/10.1080/13528165.2019.1593724

Spatz, B. 2020. Making a Laboratory: Dynamic Configurations with Transversal Video. New York: Punctum Books.

Tanakh: The Holy Scriptures. The New JPS Translation according to the Traditional Hebrew Text. Philadelphia: The Jewish Publication Society (1985).

Wolfe, P. 2016. Traces of History: Elementary Structures of Race. New York: Verso Books.

\section{RECORDINGS}

Abayudaya: Music from the Jewish People of Uganda. 2003. Recorded and with album notes by Jeffrey A. Summit. Washington, DC: Smithsonian Folkways Recordings.

Fried, A. 2010. The Baal Shem Tov's Song. New York: Sameach Music.
TO CITE THIS ARTICLE: Spatz, B, Erçin, NE, Gatt, C and Mendel, A. 2021. He Almost Forgets That There is a Maker of the World. Journal of Embodied Research, 4(2): 7 (32:06). DOI: https://doi. org/10.16995/jer.71

Submitted: 29 October 2020 Accepted: 24 July 2021 Published: 11 October 2021

COPYRIGHT:

(c) 2021 The Author(s). This is an open-access article distributed under the terms of the Attribution-NonCommercialNoDerivatives 4.0 International License (CC BY-NC-ND 4.0), which permits unrestricted use, distribution, and reproduction in any medium, provided the original author and source are credited. See https:// creativecommons.org/licenses/ by-nc-nd/4.0/.

Journal of Embodied Research is a peer-reviewed open access journal published by Open Library of Humanities. 